\title{
A Call to Arms
}

\section{Andrea Lovise Thomas}

This is not a crusade or a tirade, this is call to arms, not weapons.

The real weapons of mass destruction are those words and phrases whose constructions are designed to demolish identity and abolish diversity.

The presumption of superiority is an admission of ignorance.

Who amongst us is more than flesh and bone?

May people cease to slaughter with words that diminish by putting people in boxes that elongate to coffins in the absence of esteem.

We need to redeem our brothers and sisters in all their glorious genetic combinations and resist the temptation to create a comfortable generic.

Who amongst us is generic?

Stand up and be counted.

I don't know about you, but I don't want some watered-down, homogenized pasteurized, Anglocized version of humanity.

Is a white Australia a right Australia? 
Do we not all have the right to fight

to preserve who we really are?

Assimilation is not synonymous with disintegration.

We can all have liberty, dignity and diversity simultaneously.

What is a boat person, but a brave survivor?

What is a refugee, but a freedom fighter?

Who would not do anything to protect

family if their home was burning

and the bullets were flying?

All blood runs red.

So if we could look beyond the window dressing

it would be a blessing

because no one can see

the colour, the gender

or the ethnicity of a soul.

If we could remove the 'ist'

from our vocabulary, that would be a start.

Otherwise, we'll all end up some puff-lipped,

pale-faced, surgically modified model

of Barbie or Ken.

This is not a crusade or a tirade.

It is a call to arms.

Use them wisely. 